\section{PKC Alpha Phosphorylates Cytosolic NF-kappaB/p65 and PKC Delta Delays Nuclear Translocation of NF-kappaB/p65 in U1242 Glioblastoma Cells}

\section{U1242 Glioblastom Hücresinde PKC Alpha'nın Sitosolik NF-kappaB/p65 Fosforilize Etmedeki ve PKC Delta'nın NF-kappaB/p65 Nukleer Translokasyonundaki Rolü}

\begin{abstract}
AIM: Protein kinase-C (PKC) and NF-kappaB are involved in cell survival, proliferation, migration and radioresistance in glioblastoma multiforme (GBM). We sought to determine the interaction between PKC and NF-kappaB pathways. MATERIAL and METHODS: The activation of NF-kappaB by PKC $\alpha$ and PKC $\delta$ was assessed by Western blotting after the stimulation with Phorbol 12Myristate 13-Acetate (PMA). Gene silencing of PKC $\alpha$, PKC $\delta$ and NF$\mathrm{kappaB} / \mathrm{p} 65$ with siRNA interference was utilized to evaluate their roles in NF$\mathrm{kB}$ activation and cell proliferation.

RESULTS: PMA induced the phosphorylation of NF-kappaB/p65 by PKC $\alpha$. Gene silencing with siRNA against NF-kappaB/p65 inhibited [3H]-thymidine incorporation in U1242 GBM cells. PKC $\delta$ decelerated the nuclear translocation of activated NF-kappaB/p65 up to 4 hours after the stimulation. PMA induced death was not observed in PKC $\delta$ silenced cells where activated NF-kappaB / p65 was located immediately in the nucleus.
\end{abstract}

CONCLUSION: NF-kappaB/p65 is pro-survival and proliferative factor in U1242 GBM cells. PKC $\alpha$ is needed to phosphorylate NF-kappaB/p65. PKC $\delta$ delays the translocation of active NF-kappaB/p65 into the nucleus. PMAinduced cell death occurred if the phospho-NF-kappaB / p65 was prohibited from entering the nucleus in PKC $\delta$ positive cells. Translocation of phosphorylated form of NF-kappaB into the nucleus is critical in GBM cell proliferation.

KEYWORDS: Glioblastoma, NF-kappaB, PKC, Proliferation, Survival

ÖZ

AMAÇ:Protein kinaz C (PKC) ve NF-kappaB sinyal iletim yolları glioblastomanın yaşam, çoğalma, göç ve radyoterapiye dirençte yol alır; bu çalışmada iki yolun etkileşimi çalışılmıştır.

YÖNTEM ve GEREÇ: Phorbol 12-Myristate 13-Acetate (PMA) ile uyarılma sonrası PKC $\propto$ ve PKC $\delta$ ile NF-kappaB / p65 aktivasyonu Western blot tespit edildi. siRNA tekniği ile PKC $\alpha$ ve PKC $\delta$ gen sessizleştirilmesi NF-kappaB aktivasyonu ve hücrenin sağkalımı değerlendirildi.

BULGULAR: PKC $\alpha$ NF-kappaB / p65 proteininin fosforlanmasında rol almıştır. PKC $\delta$ ise fosforlanmış ve aktif NF-kappaB/p65'in nukleusa girmesini 4 saate kadar geciktirmiștir. U1242 hücrelerinde ölüme yol açan PMA, siRNA ile sessizleştirilen PKC $\delta$ yokluğunda NF-kappaB/p65 hemen nukleusa geçmektedir ve PMA ile hücre ölümü görülmemektedir.

SONUÇ: NF-kappaB/p65 glioblastomada bir yaşam faktörüdür ve PKC $\alpha$ fosforlanmsında; PKC $\delta$ ise nukleusa geçisinde rol almaktadır. Aktif NFkappaB / p65'in PKC $\delta$ ile hücreye geçişi geciktiğinde PMA hücre ölümüne neden olmaktadir.

ANAHTAR SÖZCÜKLER: Glioblastoma, NF-kappaB, PKC, Çoğalma, Sağkalım

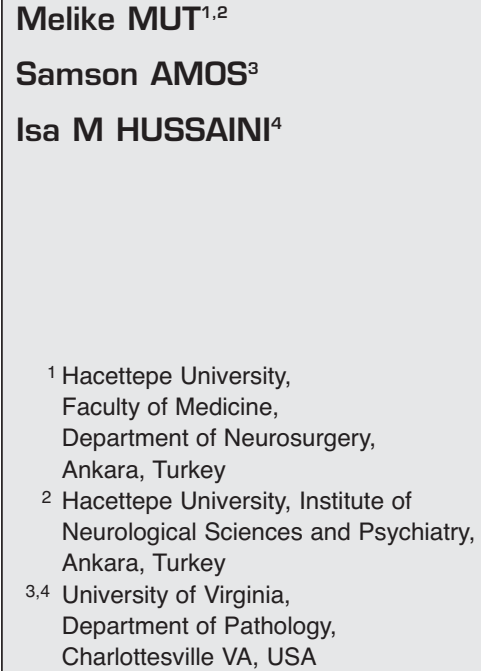

Received : 19.02.2010

Accepted : 21.04.2010

Correspondence address: Melike MUT

Hacettepe University, Faculty of Medicine, Department of Neurosurgery, Ankara, TURKEY

E-mail: melikem@hacettepe.edu.tr 


\section{INTRODUCTION}

NF-кB (Nuclear Factor- $\mathrm{B}$ ) $)^{1}$ is known to consist of a family of Rel-domain-containing proteins; Rel A (also called p65), Rel B, c-Rel, p50 (also called NFкB1), and p52 (also called NF-кB2). Phosphorylation-dependent cleavage of p100 produces p52, whereas p105 is cleaved to form p50 $(4,10,11)$.

In resting cells, $\mathrm{NF}-\mathrm{\kappa B}$ is retained in a latent form

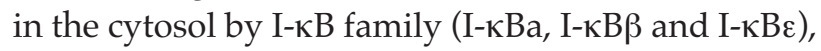
bcl-3, p105, and p100 that mask the nuclear

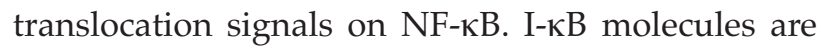
rapidly phosphorylated with cell stimulation by antigens, cytokines [tumor necrosis factor a (TNF- $\alpha$ ), interleukin 1], bacterial products (lipopolysaccharide), viruses (human T-cell leukemia virus, HIV1), environmental stress.

Depending on the stimuli, two distinct mechanisms are defined for I- $\mathrm{kB} \alpha$ phosphorylation as either serine or tyrosine phosphorylation. The most widely studied pathway is that activated by TNF- $\alpha$, Interleukin-1, or lipopolysaccharide that is regulated by phosphorylation on serine 32 and 36

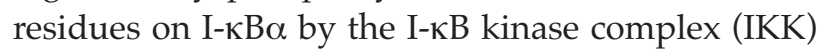
$(38,41)$. Serine phosphorylation recruits a specific ubiquitin ligase, which attaches ubiquitin molecules to the N-terminal domain of I- $\mathrm{kB}$ targeting the inhibitory subunit for degradation by the $26 \mathrm{~S}$ proteasome $(19,24)$. The second phosphorylation mechanism is mediated by tyrosine kinases at Tyrosine 42 residue. Tyrosine phosphorylation of I$\kappa \mathrm{B} \alpha$ on Tyr42 is capable of activating NF- $\kappa \mathrm{B}$ in the absence of ubiquitin-dependent degradation of I$\kappa \mathrm{B} \alpha$ (17). This pathway is stimulated by $\mathrm{H}_{2} \mathrm{O}_{2}$, pervanadate, hypoxia, or hypoxia/reoxygenation and gamma irradiation $(13,21)$.

$\mathrm{NF}-\kappa \mathrm{B}$ is a pro-survival and anti-apoptotic transcription factor in most of tumor types $(14,15)$. In addition, certain members of the NF- $\mathrm{KB}$ family are oncogenic. Several oncogenes and growth factors for

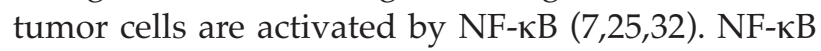
is known to be involved in radioresistance of human malignant glioma cells $(12,26,33,39)$.

Protein kinase C (PKC) represents a major cellular receptor for tumor-promoting phorbol esters $(9,20,28)$. PKC is a family of phospholipiddependent serine/threonine kinases that play important roles in signal transduction associated with a variety of cellular responses, including cell growth and differentiation, gene expression, hormone secretion, apoptosis and membrane function $(5,27,29,30,31,35,37)$. PKC consists of at least 11 isoforms that show diversity in their structures, cellular distribution, and biological functions and that have been divided into three groups based on their structures and cofactor requirements: conventional, novel and atypical (18). The conventional PKC isoforms $\alpha, \beta \mathrm{I}, \beta \mathrm{II}$, and $\gamma$ require phosphatidylserine, and $\mathrm{Ca}^{2+}$ for activity. The novel PKC isoforms $\delta, \varepsilon, \eta$ and $\theta$ do not require $\mathrm{Ca}^{2+}$ as a cofactor, but bind to phosphatidylserine when activated. Both conventional and novel PKCs are activated by phorbol 12-myristate 13-acetate (PMA) or 1,2-Diacyl-sn-Glycerol (DAG), The atypical PKC isoforms $\xi$ and $\lambda$ do not require $\mathrm{Ca}^{2+}$ and are not activated by PMA or DAG, but do bind to phosphatidylserine when activated $(27,29,31,34)$.

Glioblastoma multiforme (GBM) is the most malignant and common type of primary brain tumors. PMA induces either apoptosis or proliferative response in different subtypes of GBMs depending on differential expression of PKCs (16). The relationship between PKC activation and NF- $\mathrm{BB}$ phosphorylation and its implication in GBM survival is not well understood. The differential expression of PKCs in different subsets of GBMs and its role in NF$\kappa \mathrm{B}$ pathway may play a role in PKC-induced proliferative response in GBM cells.

\section{MATERIALS AND METHOD}

\section{Materials}

PMA and anti-tubulin antibody (DMA1) were purchased from Sigma Chemical Company (St Louis, MO). The phospho-specific (serine 536) and total antibodies against NF-кB p65 were obtained from Cell Signaling Biotechnology (Boston, MA). The PKC-specific inhibitors Gö 6976, rottlerin and bisindolylmaleimide (BIM) are products of Calbiochem (Cambridge, MA). Ingenol was purchased from RBI (Natick, MA). PKC $\delta$ antibody was obtained from Transduction Laboratories (San Diego, CA). PKC $\alpha$ antibody was from Santa Cruz Biotechnology (Santa Cruz, CA). Small interfering RNAs (siRNAs) PKC $\delta$, PKC $\alpha$ and scramble sequence (small interfering transfection control) were purchased from Dharmacon, Inc. (Lafayette, CO). NF-кB p65 siRNA was purchased from Cell 
Signaling Biotechnology (Boston, MA). The nuclear extract kit was purchased from Active Motif North America (Carlsbad, CA).

\section{Cell Cultures}

The human U-1242 Malignant Glioma (MG) cell line was kindly supplied by Dr. A. J. Yates (Ohio State University). The cell lines were originally isolated from astrocytic tumors that were designated as glioblastomas, and their characteristics have been described previously by Hussaini et al. (16]. Cell lines were regularly determined to be free of mycoplasma with reagent from Gen-Probe Inc. (San Diego). Cells were grown in modified a-minimal essential medium with $10 \%$ defined fetal bovine serum (Hyclone, Logan, UT) and $20 \mu \mathrm{g} / \mathrm{ml}$ bovine zinc insulin (25.7 IU/mg; Sigma). The cells were cultured to $100 \%$ confluence, passaged every $4-5$ days from an initial concentration of $6-8 \times 10^{3} / \mathrm{cm}^{2}$ in T flasks or 6- or 24-well plates, and cultured in astrocyte growth medium 5\% fetal bovine serum at $37^{\circ} \mathrm{C}$ in $5 \% \mathrm{CO}_{2}$ and $90 \%$ relative humidity. Prior to assays, cultures that were $80-100 \%$ confluent were washed three times with serum-free medium and kept starved for $24 \mathrm{hr}$.

\section{Methods}

\section{Western Blot Analysis}

For detecting phosphorylation, cells were grown in $60 \mathrm{cc}$ dishes and grown to $80-100 \%$ confluency, washed three times with serum-free medium and kept starved for $24 \mathrm{hr}$ in serum free $\alpha$-minimal essential medium, then treated with the pharmacological inhibitors (Gö 6976, BIM). The inhibitors were added to the cells for $30 \mathrm{~min}$ before activators (PMA and ingenol). PMA (100 nM) and Ingenol $(100 \mathrm{nM})$ were administered for $30 \mathrm{~min}$. In time dependent experiment, PMA (100 nM) was given 15, 30, 60 and $240 \mathrm{~min}$ prior to extraction into separate dishes, respectively.

After the different treatments, the cells were washed with phosphate-buffered saline (PBS; 137 $\mathrm{mM} \mathrm{NaCl}, 8.1 \mathrm{mM} \mathrm{Na}_{2} \mathrm{HPO}_{4}, 2.7 \mathrm{mM} \mathrm{KCl}$, and 1.5 $\mathrm{mM} \mathrm{KH} \mathrm{PO}_{4}$, $\mathrm{pH}$ 7.4) containing $0.2 \mathrm{mM}$ sodium orthovanadate.

For the detection of NF- $\mathrm{KB} / \mathrm{p} 65$, the rinsed cultured cells were extracted with buffer $(50 \mathrm{mM}$ Hepes, 100mM NaCl, 2mM EDTA, pH=7.5, $1 \%$ NP40, $1 \mu \mathrm{M}$ pepstatin, $1 \mu / \mathrm{mlM}$ leupeptin, $0.2 \mathrm{mM}$
PMSF, $0.2 \mathrm{mM} \mathrm{Na}$ vanadate, $2 \mu \mathrm{g} / \mathrm{ml}$ aprotinin, $40 \mathrm{mM}$ PNPP). The extract was centrifuged at $14,000 \mathrm{Xg}$ for $15 \mathrm{~min}$, boiled for $5 \mathrm{~min}$ in SDSpolyacrylamide gel electrophoresis (PAGE) buffer and separated by SDS-PAGE on $10 \%$ polyacrylamide slabs. They were electroblotted onto nitrocellulose-1 (Life Technologies, Inc.) and immunoblotting was performed with a polyclonal antibody specific for phosphorylated or total NF-KB/p65 (1:1.000). The antibodies were detected with anti-rabbit peroxidase-conjugates and final detection was carried out with ECL (Amersham Pharmacia Biotech) as described by the manufacturer.

The nuclear extract kit (Active Motif, CA) was used and manufacturer's instructions were followed for obtaining cytoplasmic and nuclear extraction. Briefly, after starving the cells for $24 \mathrm{hr}$ and administering pharmacological agents adjusted in a time dependent manner as described above, media was aspirated out of dish and washed with $5 \mathrm{ml}$ icecold PBS/phosphatase inhibitors. After aspirating rinsing PBS / phosphatase inhibitors, $3 \mathrm{ml}$ of ice-cold PBS/ phosphatase inhibitors were added. Cells were scraped from dish gently with cell lifter and centrifuged for $5 \mathrm{~min}$ at $500 \mathrm{rpm}$ in a centrifuge precooled at $4^{\circ} \mathrm{C}$. For cytoplasmic fraction collection, cells were resuspended in $250 \mathrm{ml} 1 \mathrm{X}$ Hypotonic Buffer supplied with the kit and transferred to a prechilled microcentrifuge tube, incubated for $15 \mathrm{~min}$ on ice. $25 \mathrm{ml}$ detergent was added and vortexed 10 seconds at highest setting. The suspension was centrifuged for 30 seconds at $14,000 \mathrm{Xg}$ in a microcentrifuge pre-cooled at $4^{\circ} \mathrm{C}$. Supernatant (cytoplasmic fraction) was transferred into a prechilled microcentrifuge tube. For nuclear fraction collection; nuclear pellet in $50 \mathrm{ml}$ complete lysis buffer was re-suspended and vortexed for 10 seconds at highest setting and incubated for $30 \mathrm{~min}$ on ice on a rocking platform set at $150 \mathrm{rpm}$. The suspension was vortexed for 30 seconds at highest setting and centrifuged for $10 \mathrm{~min}$ at $14,000 \mathrm{Xg}$ in a microcentrifuge pre-cooled at $4^{\circ} \mathrm{C}$. Proteins were boiled for $5 \mathrm{~min}$ in SDS-PAGE buffer. Proteins (200 $\mathrm{mg} /$ lane) were separated by SDS-PAGE on $10 \%$ polyacrylamide gels and electroblotted onto nitrocellulose and reacted with monoclonal and polyclonal antibodies. Immunoblotted proteins were detected using the ECL reagents (Amersham Biosciences) as described by the manufacturer with horseradish peroxidase-conjugated secondary antibodies (Sigma). 


\section{siRNA Transfection}

siRNAs PKC $\delta$ and PKC $\alpha$ were synthesized and purified by Dharmacon, Inc. and NF-кB p65 siRNA by Cell Signaling Biotechnology (Boston MA). PKC $\delta$ $(200 \mathrm{nM})$, PKC $\alpha(200 \mathrm{nM})$, and NF-KB $(200 \mathrm{nM})$ siRNAs were transfected separately into U-1242 MG cells using the Amaxa Nucleofector ${ }^{\mathrm{TM}}$ (Amaxa, Gaithersburg, MD). Briefly, confluent cells were trypsinized and resuspended in Amaxa Nucleofector solution $\mathrm{V}$ at a density of $2 \times 10^{6} / 100 \mu \mathrm{l}$ of solution, and either $200 \mathrm{nM}$ PKC $\delta$ siRNA or PKC $\alpha(200 \mathrm{nM})$, or NF-kB (200 nM) siRNAs were added. Cells were transfected using the A23 pulsing program. Immediately after electroporation, cells were suspended in $4.9 \mathrm{ml}$ of a-minimal essential medium plus $10 \%$ fetal bovine serum and incubated at $37^{\circ} \mathrm{C}$ for $48 \mathrm{hr}$ (22). Cells were starved for $24 \mathrm{hr}$ and the siRNA PKC $\delta$ or PKC $\alpha$ cells were treated with PMA for $30 \mathrm{~min}$ and lysed as described above. The cell and nuclear lysates were separated by SDSPAGE on $10 \%$ polyacrylamide gels. Proteins were electro-blotted onto nitrocellulose and reacted with phosphorylated NF- $\mathrm{KB}$, tubulin antibodies. The blots were stripped and reprobed with PKC $\delta$ and PKC $\alpha$ monoclonal antibodies for siRNA PKC $\delta$ or PKC $\alpha$ treated cells. The antibodies were detected with peroxidase-conjugated anti-mouse or anti-rabbit antibody, and final detection was carried out using ECL reagents as described by the manufacturer.

\section{Incorporation of $\left({ }^{3} \mathrm{H}\right]$ - Thymidine into DNA}

Relative rates of DNA synthesis were assessed by determination of $\left({ }^{3} \mathrm{H}\right]$-thymidine incorporation. U1242 MG cells transfected with either siRNA directed against PKC $\delta$ or NF- $\mathrm{NB} / \mathrm{p} 65$ were also seeded onto a 24-well plate at a density of $4.5 \times 10^{4}$. Then, the scramble sequence transfected or siRNA PKC $\delta$ or NF- $\mathrm{KB} / \mathrm{p} 65$ transfected cells were stimulated with PMA for 12 hours or 24 hours. The transfected cells were pulsed after $24 \mathrm{hr}$ of starvation. Cells were pulsed with $1 \mu \mathrm{Ci}$ of $\left({ }^{3} \mathrm{H}\right]-$ thymidine for $4 \mathrm{hr}$ and washed with PBS. This was followed by $10-\mathrm{min}$ washes with $10 \%$ trichloroacetic acid, first at $4{ }^{\circ} \mathrm{C}$ and at room temperature. Cells were dissolved overnight in $1 \mathrm{~N} \mathrm{NaOH}$, neutralized with an equal volume of $2 \mathrm{~N} \mathrm{HCl}$, and placed in scintillation fluid. $\left({ }^{3} \mathrm{H}\right]$-Thymidine incorporation was determined in a Beckman liquid scintillation counter. Thymidine uptake of cells transfected with siRNA against PKC $\delta$ or PKC $\alpha$ or NF-кB p65 were compared to that of cells transfected with scramble sequence as their control groups treated in the same way. Cells treated with inhibitors were compared to untreated U1242 MG cells.

\section{Statistical Analysis}

One-way analysis of variance was applied to depict the differences between groups and Dunnett's multiple comparison test was applied to compare to control group. A $p$ value less than 0.05 was considered to be significant.

\section{RESULTS}

Time-dependent phosphorylation of $N F-\kappa B$ and translocation into the nucleus after PMA stimulation in U1242 MG cells

PMA induced time-dependent phosphorylation of NF- $\mathrm{KB}$ at serine 536 position of p65 subunit in GBM cell line. The phosphorylation was observed as early as $15 \mathrm{~min}$ and was sustained for $240 \mathrm{~min}$. Translocation of NF-kB into the nucleus was progressively increasing within this time period (Figure 1). Total NF-kB for cytosolic proteins and histone for nuclear proteins were used as controls.

Effect of pharmacological inhibitors on phosphorylation and translocation of $N F-\kappa B$ into the nucleus after PMA stimulation in U1242 MG cells

Bisindolylmaleimide (BIM), an inhibitor of both classical and novel PKCs, was administered $30 \mathrm{~min}$ before PMA was added to the cultured cells in serum-free media for $30 \mathrm{~min}$. After PMA stimulation, the phosphorylated form of NF- $\mathrm{kB} / \mathrm{p} 65$ within the cytosol was significantly reduced by BIM $(1 \mu \mathrm{M})$ and apparently all phospho- NF-кB / p65 was immediately translocated into the nucleus. However; the classical PKC inhibitor Gö $6976(10 \mu \mathrm{M})$ partially reduced PMA-induced phosphorylation of NF-кB/p65 and caused no significant change at the nuclear fraction of NF-кB/ p65 (Figure 2).

Our results suggested that there would be at least 2 different PKCs involved in the PMA-induced activation of NF- $\mathrm{KB} / \mathrm{p} 65$; one classical PKC mainly involved in the phosphorylation of NF-KB/p65 and one novel PKC involved in the nuclear translocation of NF-kB/p65. Next, we sought to determine which PKC might have been involved. U1242 MG cells are inherently deficiency of PKC $\eta$ (16). For evaluating role of $\mathrm{PKC} \varepsilon$, ingenol at $100 \mathrm{nM}$, was utilized and there was no change observed at phosphorylated 


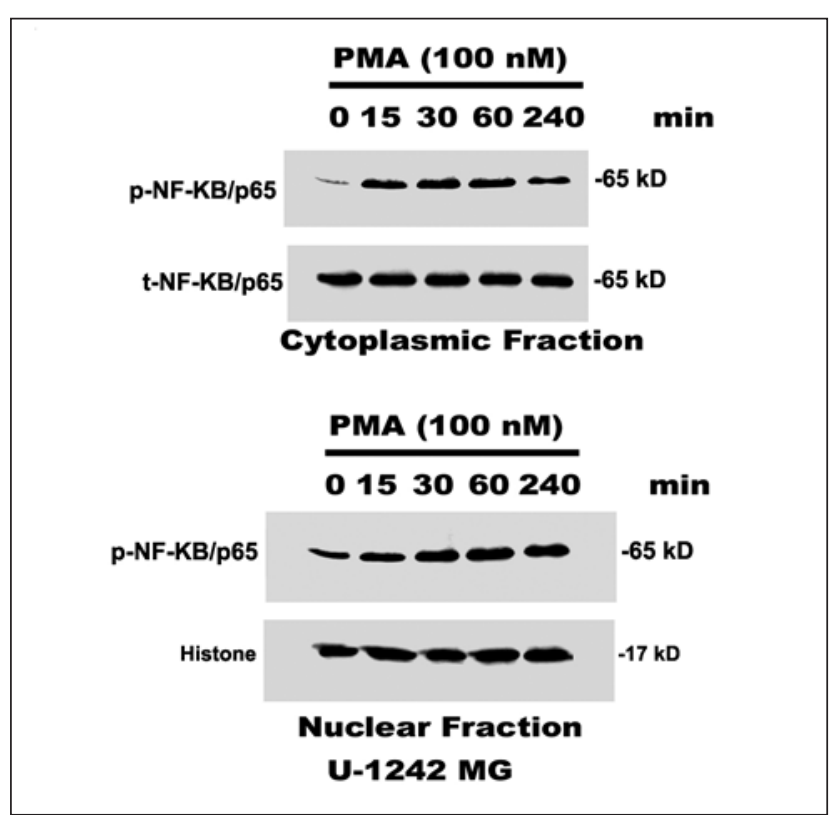

Figure 1: PMA induced phosphorylation of cytosolic NF- $\mathrm{\kappa} B$ at serine 536 residue and nuclear translocation of $N F-\kappa B$ after PMA stimulation.

U1242 MG cells were serum-starved for $24 \mathrm{~h}$ after reaching 80-100\% confluence by replacing the medium with serum-free minimal essential medium. The cells were treated with PMA (100nM) at different time points (15, 30, 60 and $240 \mathrm{~min})$. Both cytoplasmic and nuclear fractions were obtained. Protein (200 $\mu \mathrm{g} /$ lane) was fractionated by 10\% SDS-PAGE and transferred onto nitrocellulose. The nitrocellulose was reacted with primary antibody against the NF-кB p65 at serine 536 residue. Final detection was carried out using ECL reagents. Blots were stripped and re-probed for total NF-кB and histone. Western blot was representative of 3 different experiments.

levels of cytoplasmic or nuclear NF- $\mathrm{KB} / \mathrm{p} 65$ (data not shown). Neither of PKC $\varepsilon$ or $\eta$ appeared to be involved in NF- $\mathrm{\kappa B} / \mathrm{p} 65$ activation. In the next step, we determined which PKC isoforms were responsible for NF-KB pathway activation using siRNA gene silencing strategy.

Effect of siRNA PKC $\alpha$ on time-dependent phosphorylation of NF- $\mathrm{KB}$ and translocation into the nucleus

U1242 MG cells express PKC $\alpha$ at high levels and PMA stimulation activated PKC $\alpha$ (16). Gö 6976, which is a specific inhibitor of classical PKCs, partially blocked the phosphorylation of NF- $\mathrm{\kappa B}$ in several repeated experiments (Figure 2). In order to directly determine the effect of PKC $\alpha$ on NF-кB phosphorylation, and nuclear translocation, PKC $\alpha$ expression was knocked down with specific siRNA

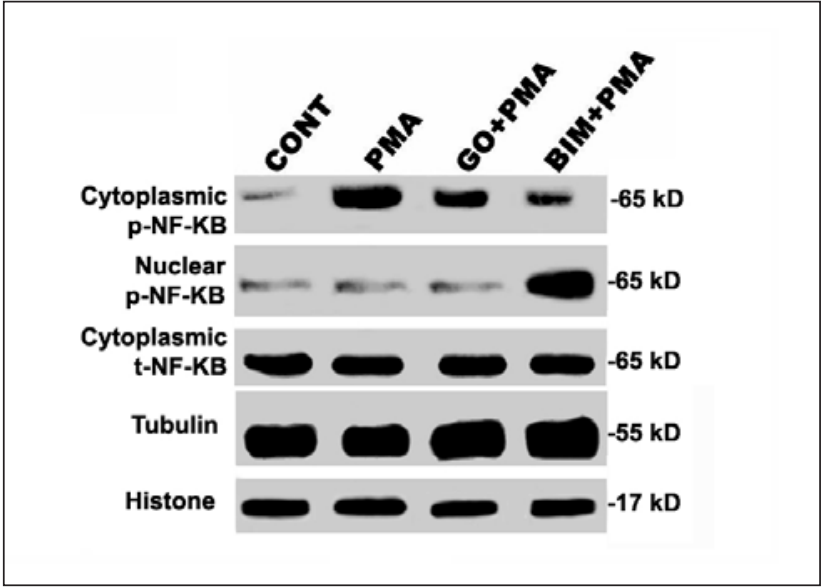

Figure 2: Effect of inhibitors on phosphorylation of cytosolic NF$\kappa B$ and translocation of $N F-\kappa B$ into the nucleus after PMA stimulation U1242 MG cells were serum-starved for $24 \mathrm{~h}$ after reaching $80-100 \%$ confluence by replacing the medium with serum-free $\alpha$ minimal essential medium. The cells were treated with BIM (1 $\mu \mathrm{M})$ or Gö 6976 (10 $\mu \mathrm{M})$ for $30 \mathrm{~min}$ before administration of PMA. The cells were treated with PMA (100nM) for $30 \mathrm{~min}$. Both cytoplasmic and nuclear fractions were obtained. Protein (200 $\mu \mathrm{g} /$ lane) was fractionated by $10 \%$ SDS-PAGE and transferred onto nitrocellulose. The nitrocellulose was reacted with primary antibody against the NF$\kappa B$ p65 at serine 536 residue. Final detection was carried out using ECL reagents. Blots were stripped and re-probed for total $N F-\kappa B \quad p 6$, histone and tubulin. Western blot was representative of 3 different experiments.

interference (Figure 3). Reduction of PKC $\alpha$ levels significantly inhibited the phosphorylation of NF- $\mathrm{KB}$ in the cytosol. However, deficiency of PKC $\alpha$ did not have a significant effect on nuclear translocation pattern of NF-кB (Figure 3).

Effect of siRNA PKC $\delta$ on time-dependent phosphorylation of $N F-\kappa B$ and translocation into the nucleus

U1242 MG cells express PKC $\delta$ at high levels and PMA stimulation activated PKC $\delta$ (16). Our results with pharmacological inhibitors and data existing for PKC expression profiling of U1242 MG cells (see above) led us to PKC $\delta$ that might have a role for the nuclear translocation of phosphorylated NF-кB/p65. The siRNA-silencing of PKC $\delta$ did not have a significant effect on phosphorylation of NF-кB/p65 in the cytosol; however, translocation of phosphoNF- $\kappa$ B/p65 into the nucleus ensued immediately and was substantially increased compared with that of non-transfected cells after PMA stimulation (Figure 4). 


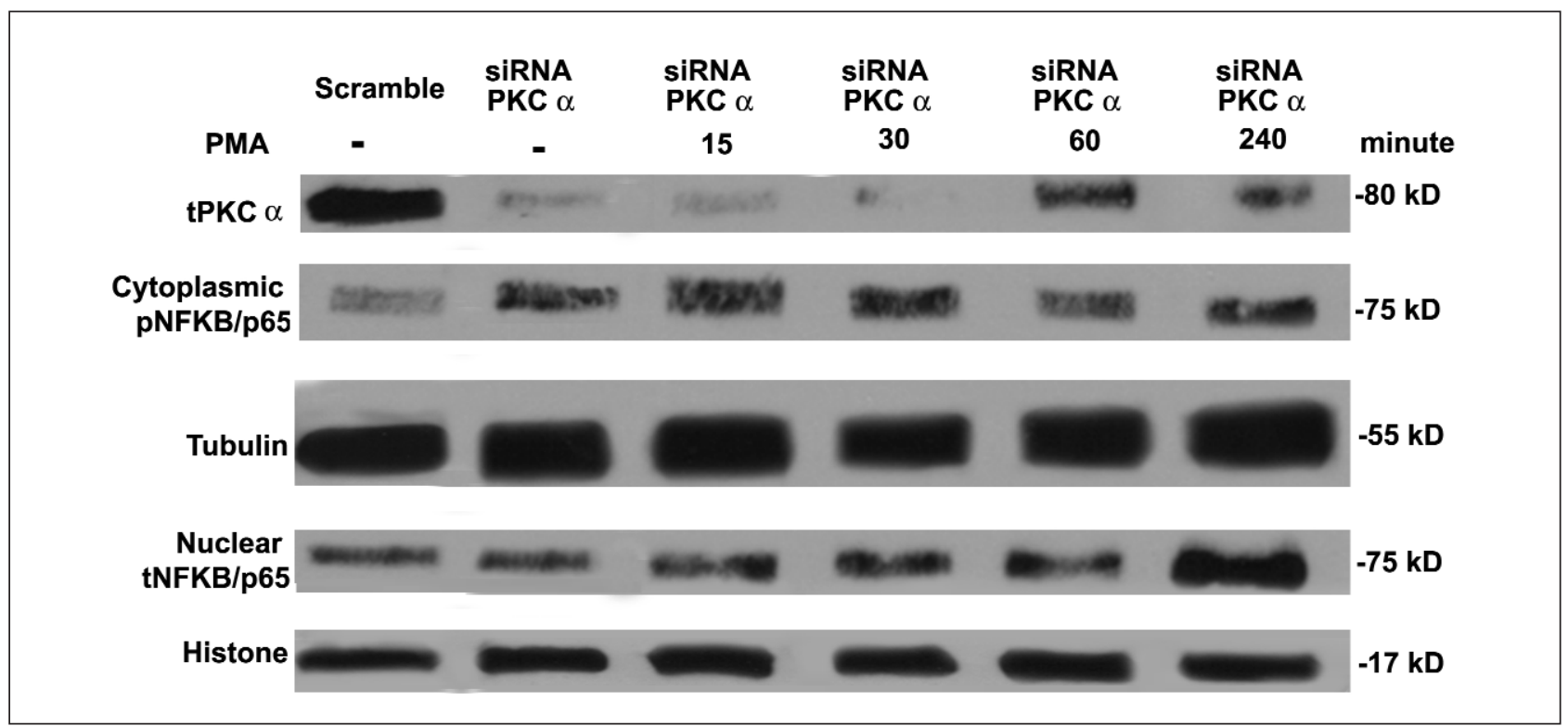

Figure 3: siRNA silencing of PKC $\alpha$ decrease phosphorylation of NF-KB p65 U1242 MG cells were transfected with siRNA PKC $\alpha$ or scramble control as described under "Methods." Cytoplasmic and nuclear fractions were obtained after the cells were treated with PMA for 15, 30, 60 and 240 minutes. Protein (200 $\mu \mathrm{g} /$ lane) was fractionated by 10\% SDS-PAGE and transferred onto nitrocellulose. The nitrocellulose was reacted with primary antibody against total $P K C \alpha, N F-\kappa B$, tubulin and histone. Final detection was carried out using ECL reagents. Western blot was representative of 2 different experiments.

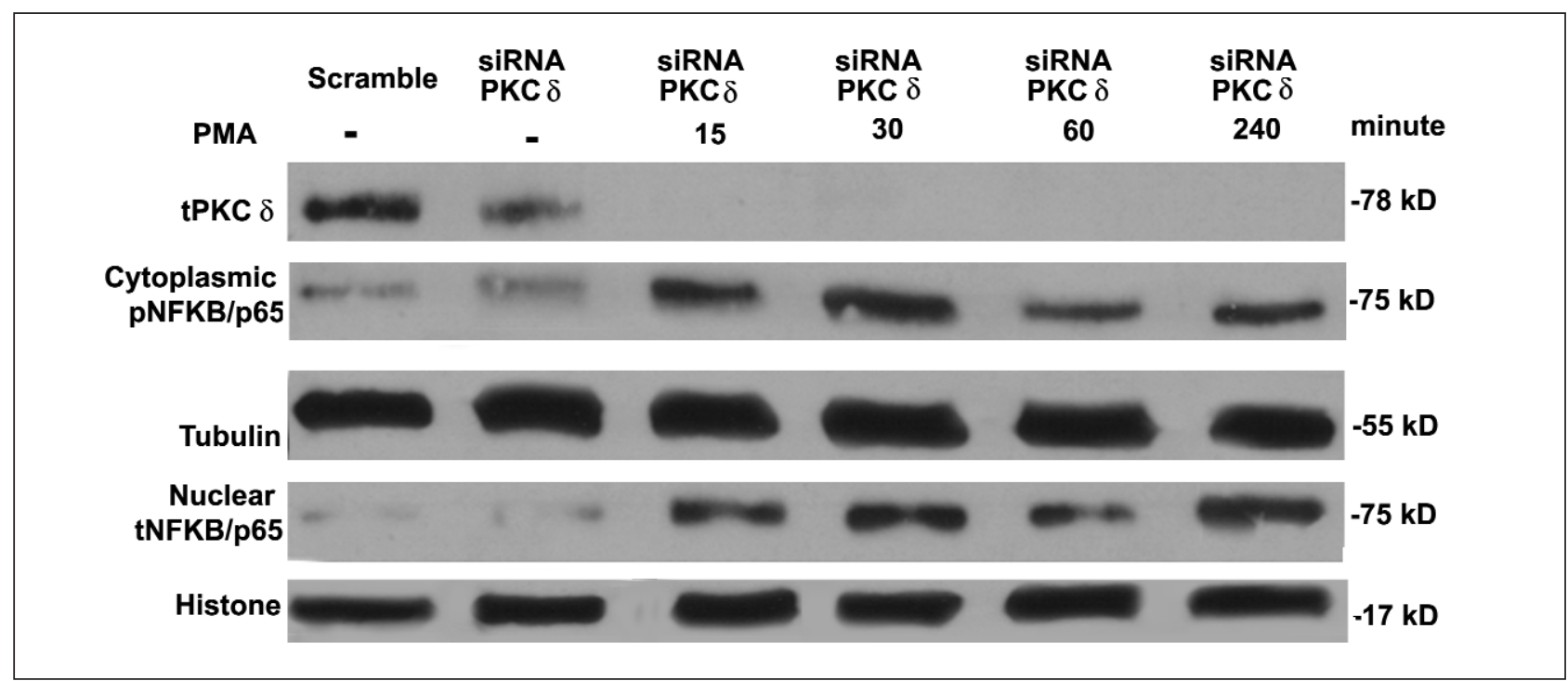

Figure 4: siRNA silencing of PKC $\delta$ increase early translocation of NF- $\mathrm{KB} / \mathrm{p} 65$ U1242 MG cells were transfected with siRNA PKC $\delta$ or scramble control as described under "Methods." Cytoplasmic and nuclear fractions were obtained after the cells were treated with PMA for 15, 30, 60 and 240 minutes. Protein (200 $\mu \mathrm{g} /$ lane) was fractionated by 10\% SDS-PAGE and transferred onto nitrocellulose. The nitrocellulose was reacted with primary antibody against total $P K C \delta, N F-\kappa B$, tubulin and histone. Final detection was carried out using ECL reagents. Western blot was representative of 2 different experiments.

Effects of deficiency of NF-кB after PMA stimulation on cellular proliferation in U1242 MG cells

NF-kB has been reported to be either proapoptotic or pro-survival transcription factor in a number of cell types. The nuclear translocation is crucial for NF- $\mathrm{\kappa B} / \mathrm{p} 65$ to exert its effects either in the direction of survival or apoptosis $(7,14,15,25,26,32,39)$ and we sought to determine the effects of deficiency of NF- $\mathrm{KB} / \mathrm{p} 65$ and how PKCs regulated its phosphorylation on cell proliferation. $\left({ }^{3} \mathrm{H}\right]-$ thymidine incorporation was used as a measure of 
cell proliferation. We have previously shown that PMA treatment of U-1242 MG cells resulted in growth arrest of the cells (16). As expected, PMA decreased cell proliferation in U1242 MG cells by $65 \%$. Only silencing with siRNA against NF-кB produced $60 \%$ inhibition of U-1242 MG cells proliferation; however, PMA stimulation did not further decrease the proliferation in NF-кB/p65 deficient cells after stimulation for 12 and 24 hours (Figure 5). Similarly, when PKC $\delta$ was knocked down, PMA was unable to induce death (Figure 6). These data suggested that NF- $\mathrm{\kappa B} / \mathrm{p} 65$ presence was essential for survival and PMA induced cell death was conducted through PKC/ NF- $\mathrm{KB} / \mathrm{p} 65$ pathway only if activated NF- $\mathrm{\kappa B} / \mathrm{p} 65$ was prohibited to enter to the nucleus by PKC $\delta$.

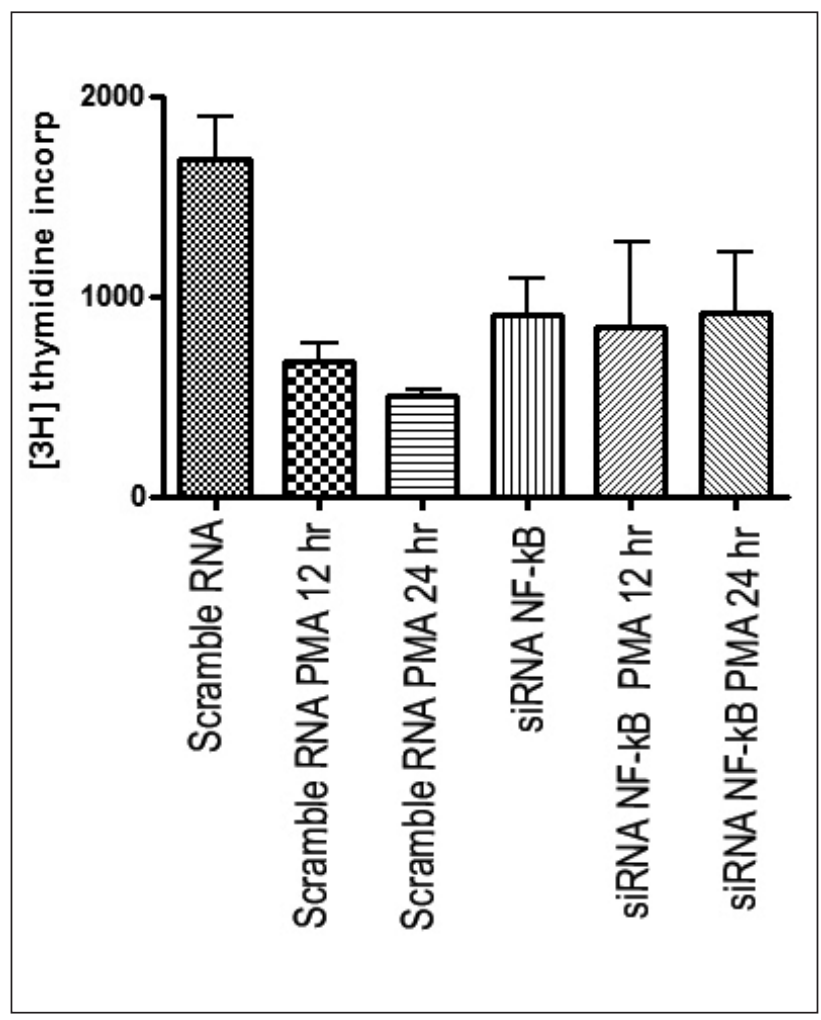

Figure 5: Deficiency of NF-КB/p65 decreases cell proliferation and blunts response to PMA induced cell death in U1242 MG cells U1242 MG cells were transfected with siRNA NF-KB/p65 and stimulated with PMA for 12 and 24 hours as described under "Methods" Cells were pulse-labeled with ( $\left.{ }^{3} \mathrm{H}\right]$ thymidine for $4 \mathrm{hr}$, and thymidine incorporation was measured using a Beckman scintillation counter. Results were from the quantitative analysis two independent experiments (means \pm S.E.), with each experiment performed in quadruplicate. Cell proliferation was calculated as percent of control.

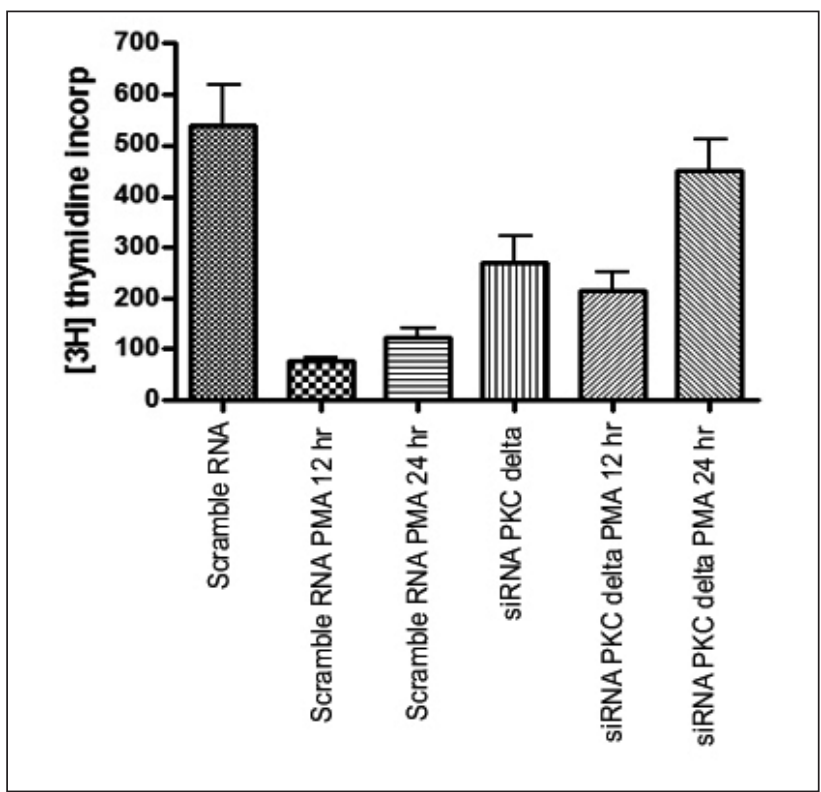

Figure 6: Deficiency of PKC $\delta$ decreases cell proliferation and reverses the response to PMA induced cell death in U1242 MG cells U1242 MG cells were transfected with siRNA PKC $\delta$ and stimulated with PMA for 12 and 24 hours as described under "Methods" Cells were pulse-labeled with ( $\left.{ }^{3} \mathrm{H}\right]$ thymidine for $4 \mathrm{hr}$, and thymidine incorporation was measured using a Beckman scintillation counter. Results were from the quantitative analysis two independent experiments (means \pm S.E.), with each experiment performed in quadruplicate. Cell proliferation was calculated as percent of control.

\section{DISCUSSION}

NF-kB proteins can form multiple homo- and hetero-dimers, each of which has distinct DNA binding site specificities and affinities resulting in activation and expression of over 100 genes, which coordinate immune, inflammatory, proliferative or apoptotic response $(3,4,10,11)$. Whether NF- $\mathrm{kB}$ acts as an inhibitor or activator of apoptosis depends on the relative levels of Rel A and c-Rel subunits (11). The pathways leading to NF-kB activation are uniquely stimulus and cell-type specific. NF-kB can be inducible or constitutively active in different cell types. The tumor-promoting phorbol ester, PMA can induce NF- $\kappa \mathrm{B}$ activity and prevent apoptosis in pancreatic carcinoma and leukemia $(8,36)$. NF- $\kappa B$ is constitutively active in most tumor cells (hematopoietic, prostate, breast cancers), rarely found to be constitutively active in normal cells except for proliferating $\mathrm{T}$ cells, B cells, thymocytes, monocytes, and astrocytes. Suppression of NF- $\mathrm{kB}$ in tumors inhibits proliferation, causes cell cycle arrest, and leads to apoptosis indicating the crucial role of 
NF- $\mathrm{KB}$ in cell proliferation and survival $(1,6)$. NF-кB is suggested to be a pro-survival and proliferative transcriptional factor in GBMs (26,39); our results supported those observations. Silencing NF-кB expression with NF-kB siRNA would reduce proliferation of GBM cells (Figure 5).

Glioblastomas represent a diverse group of tumors with several different phenotypes and genotypes; and with highly variable, differential expression profiles of PKCs (16). We demonstrate in this study that PMA-induced NF- $\mathrm{KB}$ phosphorylation was mediated by PKC $\alpha$, in addition, PKC $\delta$ seemed to delay nuclear translocation of NF- $\mathrm{KB} / \mathrm{p} 65$ because silencing this PKC isoform facilitated entry of phosphorylated NF$\kappa B / p 65$ into the nucleus (Figure 3-4). The effect of PMA on cell proliferation and survival might be regulated by differential expression of PKC in different subsets of GBMs and our results showed that NF- $\kappa B$ pathway might play a role in GBM proliferation and growth.

Among PKC isoforms, PKC $\delta$ and PKC $\alpha$ are suggested to have opposite effects in gliomas. PKC $\delta$ is generally decreased in GBMs and it is associated with apoptosis in response to gamma-irradiation, ultraviolet radiation (UV), Fas ligation and etoposide. PKC $\alpha$ is found to be responsible for the resistance to apoptosis in response to gamma irradiation and chemotherapy $(23,40)$. On the other hand, in a recent study, PMA was shown to transactivate the EGFR and increases cell proliferation by activating the PKC $\delta$ / c-Src pathway in GBMs (2). In U1242 MG cells where PKC $\delta$ was expressed, PMA stimulation led to decreased proliferation and decreased survival. Once PKC $\delta$ was knocked down, PMA stimulation resulted in proliferative response in 24 hours.

Our study demonstrates that NF- $\kappa B$ is a prosurvival and proliferative transcription factor in U1242 MG cells. PMA activation of NF-KB pathway involves at least two PKCs. In cells like U1242 MG cells, which express predominantly PKC $\alpha$ and PKC $\delta$, the former is primarily responsible for phosphorylation and activation of NF- $\mathrm{KB} / \mathrm{p} 65$ in the cytosol. However, the final transcriptional activation of NF- $\mathrm{KB} / \mathrm{p} 65$ is prevented by $\mathrm{PKC} \delta$ via delaying translocation of activated NF- $\mathrm{B} / \mathrm{p} 65$ into the nucleus. The mechanism needs to be elucidated further for the purpose of developing a new target in GBM treatment.

\section{ACKNOWLEDGMENT}

We are grateful to Joan E. Carpenter and Gerard

T. Redpath for excellent technical assistance.

\section{REFERENCES}

1. Aggarwal BB: Nuclear factor-kappaB: The enemy within. Cancer Cell 6: 203-208, 2004

2. Amos S, Martin PM, Polar GA, Parsons SJ, Hussaini IM: Phorbol 12-myristate 13-acetate induces epidermal growth factor receptor transactivation via protein kinase Cdelta / c-Src pathways in glioblastoma cells. J Biol Chem 280:7729-7738, 2005

3. Arlt A, Schafer H: NFkappaB-dependent chemoresistance in solid tumors. Int J Clin Pharmacol Ther 40:336-347, 2002

4. Baeuerle PA, Baltimore D: NF-kappaB: Ten years after. Cell 87: 13-20, 1996

5. Basu A: The potential of protein kinase $\mathrm{C}$ as a target for anticancer treatment. Pharmacol Ther 59:257-80, 1993

6. Bharti AC, Aggarwal BB: Nuclear factor-kappa B and cancer: Its role in prevention and therapy. Biochem Pharmacol 64: 883-888, 2002

7. Bhat-Nakshatri P, Sweeney CJ, Nakshatri H: Identification of signal transduction pathways involved in constitutive NFkappaB activation in breast cancer cells. Oncogene 21: 20662078, 2002

8. Busuttil V, Bottero V, Frelin C, Imbert V, Ricci J E, Auberger P, Peyron J F: Blocking NF-kappaB activation in Jurkat leukemic $\mathrm{T}$ cells converts the survival agent and tumor promoter PMA into an apoptotic effector. Oncogene 21:3213-3224, 2002

9. Castagna M, Takai Y, Kaibuchi K, Sano K, Kikkawa U, Nishizuka Y: Direct activation of calcium-activated, phospholipid-dependent protein kinase by tumor-promoting phorbol esters. J Biol Chem 257: 7847-7851, 1982

10. Chen FE, Ghosh G: Regulation of DNA binding by Rel/NFkappaB transcription factors: Structural views. Oncogene 18:6845 6852, 2003

11. Chen X, Kandasamy K, Srivastava RK: Differential roles of RelA (p65) and c-Rel subunits of nuclear factor B in tumor necrosis factor-related apoptosis-inducing ligand signaling. Cancer Res 63:1059 -1066, 2003

12. Ding GR, Honda N, Nakahara T, Tian F, Yoshida M, Hirose H, Miyakoshi J: Radiosensitization by inhibition of IkappaBalpha phosphorylation in human glioma cells. Radiat Res 160: 232-237, 2003

13. Fan C, Li Q, Ross D, Engelhardt JF: Tyrosine phosphorylation of I kappa B alpha activates NF kappa B through a redoxregulated and c-Src-dependent mechanism following hypoxia/reoxygenation. J Biol Chem 278:2072-2080, 2003

14. Foo S, Nolan G: NF- B to the rescue. Trends Genet 15:229-235, 1999

15. Greten FR, Karin M: The IKK/NF-kappaB activation pathway- a target for prevention and treatment of cancer. Cancer Lett 206: 193-199, 2004

16. Hussaini IM, Karns LR, Vinton G, Carpenter JE, Redpath GT, Sando JJ, VandenBerg SR: Phorbol 12-myristate 13-acetate induces protein kinase ceta-specific proliferative response in astrocytic tumor cells. J Biol Chem 275: 22348-22354, 2000 
17. Imbert V, , Rupec RA, Livolsi A, Pahl HL, Traenckner EB, Mueller-Dieckmann C, Farahifar D, Rossi B, Auberger P, Baeuerle PA, Peyron JF: Tyrosine phosphorylation of IKBalpha activates NFKB without proteolytic degradation of IKBalpha. Cell 86: 787-798, 1996

18. Jaken S: Protein kinase $C$ isozymes and substrates. Curr Opin Cell Biol 8: 168-173, 1996

19. Karin M: The beginning of the end: I B kinase (IKK) and NFB activation. J Biol Chem 274:27339-27342, 1999

20. Leach KL, James ML, Blumberg PM: Characterization of a specific phorbol ester aporeceptor in mouse brain cytosol. Proc Natl Acad Sci USA 80: 4208-4212, 1983

21. Livolsi A, Busuttil V, Imbert V, Abraham RT, Peyron JF: Tyrosine phosphorylation-dependent activation of NF-kappa B. Requirement for p56 LCK and ZAP-70 protein tyrosine kinases. Eur J Biochem 268:1508-1515, 2001

22. Maasho K, Marusina A, Reynolds NM, Coligan JE, Borrego F J: Efficient gene transfer into the human natural killer cell line, NKL, using the Amaxa nucleofection system. Immunol Methods 284:133-140, 2004

23. Mandil R, Ashkenazi E, Blass M, Kronfeld I, Kazimirsky G, Rosenthal G, Umansky F, Lorenzo PS, Blumberg PM, Brodie C: Protein kinase Calpha and protein kinase Cdelta play opposite roles in the proliferation and apoptosis of glioma cells. Cancer Res 61:4612-4619, 2001

24. May M, Ghosh S: Signal transduction through NF- B. Immunol Today 19:80-88, 1998

25. Mayo MW, Norris JL, Baldwin AS: Ras regulation of NFkappa B and apoptosis. Methods Enzymol 333: 73-87, 2001

26. Miyakoshi J, Yagi K: Inhibition of I kappaB-alpha phosphorylation at serine and tyrosine acts independently on sensitization to DNA damaging agents in human glioma cells. Br J Cancer 82:28-33, 2000

27. Newton A C: Protein kinase C: structure, function, and regulation. J Biol Chem 270: 28495-28498, 1995

28. Niedel JE, Kuhn LJ, Vandenbark GR: Phorbol diester receptor copurifies with protein kinase C. Proc Natl Acad Sci USA 80: 36-40, 1983

29. Nishizuka Y: The role of protein kinase $C$ in cell surface signal transduction and tumour promotion. Nature 308:693-698, 1984
30. Nishizuka Y: The molecular heterogeneity of protein kinase $C$ and its implications for cellular regulation. Nature 334: 661665, 1988

31. Nishizuka Y: Protein kinase $C$ and lipid signaling for sustained cellular responses. FASEB J 9:484-496, 1995

32. Pahl HL: Activators and target genes of Rel/NF-kappaB transcription factors. Oncogene 18:6853-6866, 1999

33. Ravi R, Bedi G C, Engstrom L W, Zeng Q, Mookerjee B, Gelinas C, Fuchs E J, Bedi A: Regulation of death receptor expression and TRAIL/Apo2L-induced apoptosis by NFkappaB. Nat Cell Biol 3:409-416, 2001

34. Ron D, Kazanietz M G: New insights into the regulation of protein kinase $\mathrm{C}$ and novel phorbol ester receptors. FASEB J 13:1658-1676, 1999

35. Stabel S, Parker P: Protein kinase C. Pharmacol Ther 51:71-95, 1991

36. Trauzold A, Wermann H, Arlt A, Schutze S, Schafer H, Oestern S, Roder C, Ungefroren H, Lampe E, Heinrich M, Walczak H, Kalthoff H: CD95 and TRAIL receptor-mediated activation of protein kinase $\mathrm{C}$ and NF-kappaB contributes to apoptosis resistance in ductal pancreatic adenocarcinoma cells. Oncogene 20:4258-4269, 2001

37. Toker A: Signaling through protein kinase C. Front Biosci 3: 1134-1147, 1998.

38. Verma IM, Stevenson JK, Schwarz EM, Van Antwerp D, Miyamoto S: Rel/NF-kappaB / I kappa B family: intimate tales of association and dissociation. Genes Dev 9: 2723-2735, 1995

39. Yamagishi N, Miyakoshi J, Takebe H: Enhanced radiosensitivity by inhibition of nuclear factor kappa B activation in human malignant glioma cells. Int J Radiat Biol 72: 157-162, 1997

40. Yuan ZM, Utsugisawa T, Ishiko T, Nakada S, Huang Y, Kharbanda S, Weichselbaum R, Kufe D: Activation of protein kinase $\mathrm{C}$ delta by the $\mathrm{c}-\mathrm{Abl}$ tyrosine kinase in response to ionizing radiation. Oncogene 16:1643-, 1998

41. Zandi E, Rothwarf DM, Delhase M, Hayakawa M, Karin M: The IkappaB kinase complex (IKK) contains two kinase subunits, IKKalpha and IKKbeta, necessary for IkappaB phosphorylation and NF-kappaB activation. Cell 91: 243-252, 1997 